In this issue:

Louise Giles, 1930-1976

ALA Minority Scholarship Renamed for Louise Giles

ACRL Board Pays Tribute to Louise Giles

Stanford Authorizes New Library

News from the Field

Publications

People

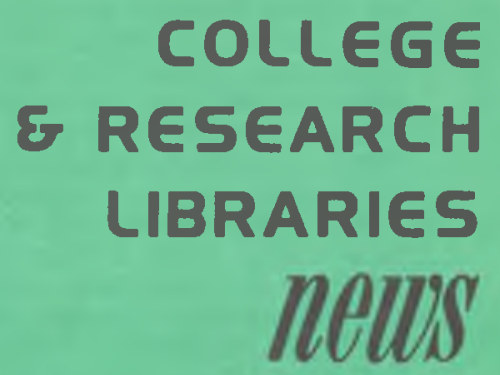

NO. 3 MARCH 1977

\title{
Louise Giles, 1930-1976
}

Louise Jones Giles, 46, outstanding in the field of community college learning resource centers, a leader in the American Library Association, and past president of the Association of College and Research Libraries, died on December 31, 1976. Detroit firemen responding to a fire in her home discovered the bodies of Louise and her husband of 23 years at about 6:30 a.m.

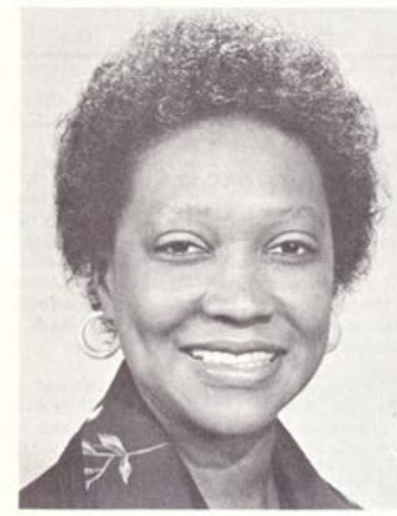

Mrs. Giles was born in Aragon, Georgia, on April 20, 1930. She received her B.A. in foreign languages from the University of Akron in 1952 and her M.S. in library science from Drexel Institute of Technology in 1953 (Alice B. Kroeger Scholarship recipient). In 1953 she received the Buenos Aires Convention Fellowship to spend one year as an exchange student in Tegucigalpa, Honduras. She had completed course work for her doctorate from the Center for the Study of Higher Education at the University of Michigan.

At the time of her death, Mrs. Giles was dean of learning resources at Macomb County Community College, Warren, Michigan, a position she had held since March 1970. Although her contributions were most instrumental in the growth and influence of learning resources, her influence and insight will be sorely missed throughout the college. Prior work experiences were positions as associate dean of learning resources at Oakland Community College, first at Highland Lakes Campus, Union Lake, Michigan, and then at Orchard Ridge Campus, Farmington, Michigan, in 1965-70, and head of the foreign language collection and first assistant, young adult and adult librarian at Detroit Public Library in 1953-65.

Mrs. Giles was active in the American Library Association (past president of ACRL, past chairman of the Community and Junior College Libraries Section, member of many ALA committees), Michigan Library Association, Association for Educational Communications and Technology, Michigan Association of Administrators of Learning Resources, National Society for Programmed Instruction, Michigan Association of Community College Instructional Administrators, and Michigan Academy of Science, Arts and Letters. She had served on accreditation teams for both the North Central Association and the Middle States Association Commission of Higher Education and had just completed an accreditation visit for the Middle States Association at the Caribbean Jumior College, Puerto Rico, in November.

Mrs. Giles had been appointed a member of the Library Advisory Committee which was es- 
tablished by Dr. Daniel J. Boorstin, Librarian of Congress, to review the LC operation with an eye toward reorganization.

She was a recipient of the John S. Brubacher Award from the Center for the Study of Higher Education at the University of Michigan in 1975 for her outstanding graduate essay on the history and philosophy of higher education.

Her publications included: Aspects of the Junior College Field, A Bibliography, AACJC, 1969; "Planning Community College Resource Centers," American Libraries, January 1971; "Focus on Community College Libraries," Michigan Librarian, Summer 1971; “The Black Librarian as Change Agent" in What Black $\mathrm{Li}$ brarians Are Saying, edited by E. J. Josey, Scarecrow Press, 1972; "On the Cutting Edge of Change" in New Dimensions in Academic Library Service, edited by E. J. Josey, Scarecrow Press, 1973.

Edwin C. Giles attended Kent State University. He was graduated from Wayne State University, Detroit, Michigan, with a master of arts degree in administration. He taught in the school system of Detroit and for the past few years he was principal of the Scripps Elementary School.

Mr. and Mrs. Giles are survived by their daughter, Susan, 19, who is a student at City University of New York; her mother, Mrs. Roberta Glenn; her sister, Mrs. Elsie Ashworth; and his mother, Mrs. Doll Giles, all of Akron, Ohio. Memorial contributions may be made to the Detroit Chapter of the NAACP, 2990 E. Grand Blvd., Detroit, MI 48202; Big Brothers of Detroit, 15800 W. McNichols, Detroit, MI 48235; or the Minority Scholarship Fund, ALA, 50 E. Huron St., Chicago, IL 60611.

\section{ALA MINORITY SCHOLARSHIP RENAMED FOR LOUISE GILES}

The following resolution was unanimously endorsed by the Board of Directors of the Association of College and Research Libraries and the ALA Awards Committee. It was approved by the ALA Council on February 1, 1977.

WHEREAS Louise Giles had served extensively and in a most dedicated manner the profession of librarianship, the American Library Association, and the academic and educational fields as: a leader among the ACRL Community and Junior College Libraries Section, serving in a number of offices, including that of Chairman; a leader in the Association of College and Research Libraries, serving as its President in 1975/76; and a leader in the cooperative and advisory programs between the American Library Association and the American Association of Com- munity and Junior Colleges; and

WHEREAS her untimely death has been a tragic loss and will continue to deprive the library world of her valuable assistance;

THEREFORE BE IT RESOLVED that the Council of the American Library Association recognize her loss by a moment of silence; and

BE IT FURTHER RESOLVED that she be remembered by naming the ALA Scholarship Program-Minority Scholarship as the Louise Giles Minority Scholarship; and

BE IT FURTHER RESOLVED that ALA members and other friends be invited to contribute to this fund.

\section{Fulbright-Hays Scholars}

The Fulbright-Hays scholars in library science for 1976-77 are:

GEORGE BoBINSKI-dean and professor, information and library studies, State University of New York, Buffalo. Library science, University of Warsaw, Poland, March-June 1977. Lecturing.

Allan D. Prate-assistant professor of library science, Indiana University, Bloomington. Library automation and information science, Danish Library School, Denmark, September 1976-June 1977. Lecturing.

News items for inclusion in C\&RL News should be sent to John $Y$. Crowley Assistant Director of Libraries, Milne Library, State University College, Oneonta, NY 13820. Advertising (including classified ads) should be sent to Leona Swiech, Advertising Office, American Library Association, 50 E. Huron St., Chicago, IL 6061I. Production and circulation matters are handled by ALA Central Production Unit, at the above address.

News editor: John V. Crowley, Assistant Director of Libraries, Milne Library, State University College, Oneonta, NY 13820 . Editor: Richard D. Johnson. Milne Library, State University College, Oneonta, New York 13820. President, ACRL:

Connie R. Dunlap. Executive Secretary, ACRL: to be announced.

College Research Libraries is published by the Association of College and Research Libraries, a division of the American Library Association, 17 times yearly-6 bimonthly journal issues and II monthly (combining July-August) News issues-at 1201.05 Bluff St., Fulton, MO 65251. Subscription, $\$ 15.00$ a year, or to members of the division \$7.50, included in dues. Second-class postage paid at Fulton, Missouri 65251 .

(C) American Library Association 1977. All material in this journal subject to copyright by the American Library Association may be photocopied for the noncommercial purpose of scientific or educational advancement. 